\title{
Intestinal Repair in Chronically Undernourished Rabbits
}

\author{
CELINA GUZMAN AND J. RICHARD HAMILTON
}

The Research Institute, The Hospital for Sick Children Division of Gastroenterology, Department of Pediatrics, The University of Toronto, Toronto, Ontario, Canada

\begin{abstract}
To assess the effect of chronic undernutrition on intestinal epithelial repair after injury, we studied 10wk-old rabbits, nutritionally deprived for 6 wk (body weight $1.95 \pm 0.2 \mathrm{~kg}$ versus controls, $2.68 \pm 0.7 \mathrm{~kg}, p<0.001$ ). Intestinal structure and function were assessed 4, 24, 48, 72 , or $96 \mathrm{~h}$ after a 90 -min vascular occlusion of a $20-\mathrm{cm}$ segment of midintestine in undernourished and control-diet animals. Tritiated thymidine autoradiography showed that movement of epithelial cells along the crypt-villus axis was significantly curtailed in undernourished rabbits after sham operation or after ischemic injury. In sham-operated rabbits, no significant differences were observed in mucosal structure, disaccharidase and Na-K-ATPase activities, or $\mathrm{Na}$ transport (Ussing chambers) between nutritionally deprived and control diet rabbits. Four and $24 \mathrm{~h}$ after ischemic injury, significant but similar structural and functional small intestinal abnormalities occurred in both diet groups; recovery of enzyme function was not significantly delayed but crypt-villus length recovery was minimally delayed in undernourished rabbits. Glucose-stimulated $\mathrm{Na}$ absorption diminished in short circuited jejunum from malnourished but not from control diet animals $24 \mathrm{~h}$ after injury and was normal in both diet groups at $72 \mathrm{~h}$. After transient small intestinal villus cell injury we observed suppressed epithelial proliferation but no consistent impact on epithelial differentiation in nutritionally deprived rabbits. (Pediatr Res 20: 1301-1304, 1986)
\end{abstract}

\section{Abbreviations}

Isc, short circuit current

Na-K-ATPase, sodium-potassium-dependent ATPase $\mathrm{PD}$, potential difference

$\Delta$ Isc, transmucosal Isc

\section{MATERIALS AND METHODS}

Beginning at $4 \mathrm{wk}$ of age, when they weighed $1.2 \pm 0.2 \mathrm{~kg}$ (mean \pm SEM), New Zealand White rabbits, each day, received $50 \%$ of the daily intake of a control ad libitum fed group, for 6 wk. Preliminary experiments had established that any dietary restriction in excess of $50 \%$ of control diet caused restlessness, aggressive behavior, and a significant death rate. All rabbits received conventional Rabbit Chow (Ralston Purina Company, Raleigh, NC) and had free access to water. As shown in Figure 1 , the deprived diet group gained less weight, $1.95 \pm 0.2 \mathrm{~kg}$, than the ad libitum fed controls, $2.68 \pm 0.7 \mathrm{~kg}$ (mean \pm SEM) over the 6-wk study period $(p<0.001)$.

After this 6-wk period, rabbits from both dietary groups, at random, underwent general anaesthesia and either a sham laparotomy or mesenteric arterial clamping in which the vascular supply to a $20-\mathrm{cm}$ segment of midintestine was occluded for 90 min using techniques similar to those described for the rat (3). Preliminary experiments had determined that longer periods of vascular occlusion caused irreversible necrosis while shorter periods failed to produce significant injury. Serosal sutures were placed at the proximal and distal ends of the occluded segment for later identification. The sham laparotomy procedure consisted of an abdominal incision and manipulation but no occlusion of mesenteric vessels. Animals were killed 4, 24, 48, 72, or $96 \mathrm{~h}$ after operation by parenteral Na pentobarbital. For microscopy and enzyme assays we used 52 animals, for ion flux studies, 32 , and for autoradiographic measurements, 16 animals.

For structural measurements by light microscopy, 2-cm sections were fixed first in Bouin's solution, then transferred to $70 \%$ alcohol, blocked in paraffin, and stained with hematoxylin and eosin. We measured a minimum of 10 crypt-villus units in

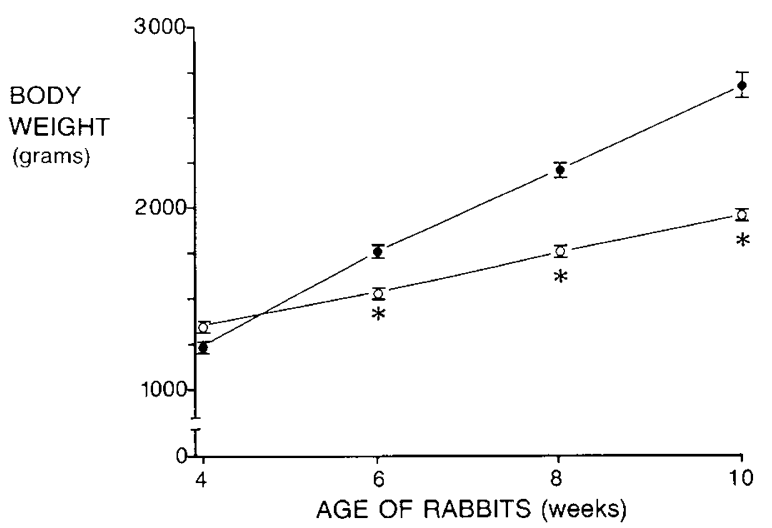

Fig. 1. Body weights, control $(\bullet)$ and undernourished rabbits $(O)$ during a 6 -wk period (mean \pm SEM). Undernourished group weighed less at ages 6,8 , and 10 wk. ${ }^{*} p<0.001$.
Chronic dietary deprivation has been shown in several species to inhibit epithelial renewal in the small intestine (1). We postulated that in the chronically undernourished subject, epithelial repair might be delayed after injury. In fact, a recent study in our laboratory found that chronically under nourished piglets exhibited relatively prolonged recovery from the extensive lesion of experimental viral enteritis (2). The present experiments examine functional and structural intestinal recovery after transient ischemic injury to short segment of mid-small intestine in rabbits subjected to chronic dietary deprivation.

Received May 30, 1986; accepted July 24, 1986.

Address reprint requests to Dr. J. R. Hamilton, The Hospital for Sick Children, 555 University Avenue, Toronto, Ontario Canada M5G IX8.

Supported by grants from the Programme for Control of Diarrheal Diseases of the World Health Organization and the Medical Research Council of Canada. C. G. received grants from the International Development Research Center of Canada, and the Hospital for Sick Children Foundation. 
properly oriented sections using a calibrated micrometer eye piece.

For autoradiographic cell migration studies, rabbits were injected intraperitoneally with ${ }^{3} \mathrm{H}$ thymidine (New England $\mathrm{Nu}-$ clear, Boston, MA, specific activity $78 \mathrm{Ci} / \mathrm{mmol}) 0.5 \mathrm{mCi} / \mathrm{g}$ of body weight, at the time of the vascular clamping or sham procedure, and killed 4 or $24 \mathrm{~h}$ later. Jejunal tissue sections, fixed as described above, were dip-coated with Kodak NTB-2 Nuclear Tract emulsion, and exposed for $3 \mathrm{wk}$ (4). For measurements of cell migration a cell was considered labeled when at least 4 grains were seen over the nucleus. We used a calibrated eye piece to measure distance between the crypt base and the foremost labeled cell along the crypt villus unit and calculated enterocyte migration rates from cell positions at 4 and $24 \mathrm{~h}$.

For mucosal enzyme assays, the ischemic segment of small intestine or the corresponding segment in sham-operated animals was removed quickly, flushed with ice cold normal saline and opened; the mucosa was scraped off with a glass slide and homogenized with $2.5 \mathrm{mM}$ EDTA, $100 \mathrm{mg} / \mathrm{ml}$. Sucrase and lactase activities were measured by the method of Dahlqvist (5), thymidine kinase by a modification (6) of the method of Klemperer and Haynes (7), and Na-K-ATPase as described by Kelly et al. (8).

In Ussing chambers we measured glucose-facilitated Na flux under short-circuited conditions in mucosa from injured and control segments of mid-small intestine. Segments were removed, flushed with ice-cold normal saline, placed in oxygenated chamber buffer (Krebs Ringer bicarbonate), and slipped over a glass rod where muscular and visceral peritoneal layers were removed. The remaining mucosa was opened into sheets and mounted in conventional Ussing chambers, exposing an area of $1.29 \mathrm{~cm}^{2}$ to buffer. Both sides of the tissue were bathed with equal volumes

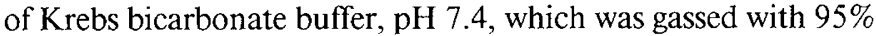
$\mathrm{O}_{2}$ and $5 \% \mathrm{CO}_{2}$ and kept at $37^{\circ} \mathrm{C}$. This buffer was constituted

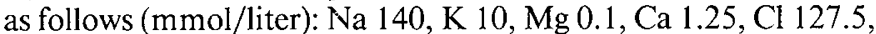
$\mathrm{HCO}_{3} 25$, and $\mathrm{H}_{2} \mathrm{PO}_{4} 2$. After preliminary experiments established that tissue viability was enhanced by the inclusion of 10 $\mathrm{mM}$ glucose in the serosal buffer, this concentration of serosal glucose was used, osmotically balanced with mannitol in the mucosal buffer. PD, total conductance, and ISC were measured at 10-min intervals and transmucosal PD neutralized from an appropriate current source as previously described (9). All tissues were studied first under basal conditions for $45 \mathrm{~min}$, and then in the presence of glucose $30 \mathrm{mM}$ added to both mucosal and serosal chambers during $55 \mathrm{~min}$.

After equilibration periods of $15 \mathrm{~min}$ in the basal state and in the presence of glucose, unidirectional and net ion fluxes were measured with tracer quantities of ${ }^{22} \mathrm{Na}$ added either to the serosal or mucosal side of paired tissues. Reservoirs were sampled at 10 -min intervals and ion fluxes were circulated during standard equations (9). Statistical comparisons were made using Student's unpaired $t$ test.

\section{RESULTS}

No apparent clinical differences were seen between dietary groups in their general or their intestinal response to intestinal injury.

Light microscopy. In both dietary groups, vascular occlusion caused a typical ischemic lesion in the intestine of the injured segment with submucosal and subserosal hemorrhage seen at 4 and $24 \mathrm{~h}$. Small intestinal mucosal measurements for each group are summarized in Figure 2. In sham-operated animals, dietary deprivation had no effect on total crypt-villus length. Four hours after ischemic injury, crypt-villus lengths were similarly reduced in both diet groups $(p<0.05)$. By $24 \mathrm{~h}$, crypt-villus length had returned to normal in control diet animals but in the malnourished group, it remained blunted. By $48 \mathrm{~h}$ after injury, these microscopic measurements were normal in both dietary groups.

Autoradiography. Measurements of epithelial cell position at

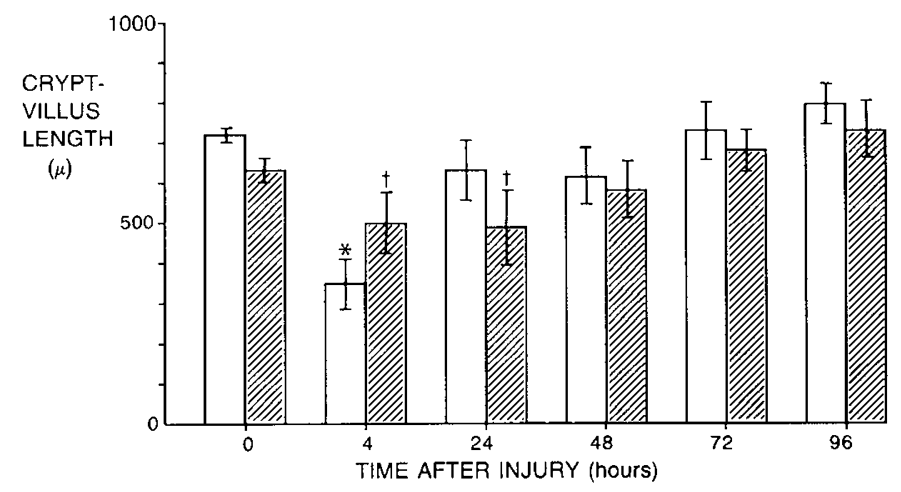

Fig. 2. Crypt-villus length in control diet (open bars) and undernourished rabbits (shaded bars) after ischemic injury (mean $\pm \mathrm{SEM}$ ). After significant decrease in both diet groups at $4 \mathrm{~h}$, control group returned to normal at $24 \mathrm{~h}$, undernourished at $48 \mathrm{~h} .{ }^{*} \mathrm{p}<0.05$ compared with control diet sham-operated group; $\uparrow p<0.05$ compared with sham undernourished.

intervals after ${ }^{3} \mathrm{H}$-thymidine injection are summarized in Table 1 for the different study groups. In sham-operated animals, labeled cells were located in the crypts $4 \mathrm{~h}$ after injection of the label, administered at the time of operation in both diet groups; the position of the foremost labeled cell was $52 \pm 2 \mu$ (mean \pm SEM) from the crypt base in control diet rabbits versus $43 \pm 2 \mu$ in the deprived-diet group $(p<0.01)$. Twenty-four $\mathrm{h}$ after thymidine injection, foremost labeled cells in undernourished animals were $120 \pm 3 \mu$ from the crypt base, a lesser distance than those in sections from control diet rabbits $(158 \pm 4 \mu)(p<$ 0.001 ). After ischemic injury foremost labeled cells had traveled significantly further than those in sham-operated animals (control diet, injured versus sham, $231 \pm 7$ versus $158 \pm 5$, undernourished, $201 \pm 5$ versus $120 \pm 3, p<0.001$ ) but the distances traveled by these cells at $24 \mathrm{~h}$ were significantly less in undernourished animals compared with control diet rabbits, for the sham-operated groups $(p<0.001)$ and for the ischemic injury groups $(p<0.005)$. Migration rates calculated from these means were greatly reduced in undernourished rabbits, $3.9 \mu / \mathrm{h}$ for sham operated, and $7.4 \mu / \mathrm{h}$ for ischemic injury animals, compared with 5.3 and $9.1 \mu / \mathrm{h}$, respectively, in control diet animals.

Mucosal enzymes. In sham-operated animals, jejunal sucrase specific activities did not differ between dietary groups (138 \pm 12 versus $113 \pm 14 \mu / \mathrm{g}$ protein, control versus deprived diet), in animals $4 \mathrm{~h}$ after ischemia, when levels were less $(27 \pm 9$ versus $48 \pm 8 \mu / \mathrm{g}$ protein $p<0.05)$ than those of sham-operated controls, and in animals $72 \mathrm{~h}$ after ischemia when activities were normal (Fig. 3). Lactase activities too, were similar in both dietary groups, although in the undernourished group, normal levels were achieved at $48 \mathrm{~h}$ and not until $72 \mathrm{~h}$ in control diet animals (Fig. 3). Na-K-ATPase activities followed the same pattern as sucrase activities. Levels of this basolateral enzyme activity in undernourished animals did not differ from those in control diet animals for sham-operated groups $(74 \pm 8$ versus $68 \pm \mu / \mathrm{g}$ protein, control versus malnourished). Four h after injury, NaK-ATPase specific activity was diminished $(p<0.05)$ in both dietary groups but recovered by $72 \mathrm{~h}$ in control and deprived diet rabbits (Fig. 3). Thymidine kinase activity, a marker of cell proliferation, increased in control diet rabbits $4 \mathrm{~h}$ after ischemia $(4.7 \pm 0.6$ versus $8 \pm 1 \mu / g$ protein) with further increases at 24 $\mathrm{h}$, returning to normal by $48 \mathrm{~h}$. This rise was delayed in the malnourished animals; it was not apparent until $24 \mathrm{~h}$, and it returned to normal by $48 \mathrm{~h}$.

Sodium transport. Table 2 summarizes unidirectional and net intestinal sodium fluxes for each study group measured under basal conditions and in the presence of $30 \mathrm{mM}$ D-glucose. Glucose-Na cotransport, like the disaccharidases, is a feature of 
Table 1. ${ }^{3} H$-thymidine autoradiography, small intestinal epithelium, before and after ischemic injury in control diet and deprived diet rabbits* (mean $\pm S E M)$

\begin{tabular}{|c|c|c|c|c|c|c|c|}
\hline & \multicolumn{2}{|c|}{ Sham operated } & \multirow[b]{2}{*}{$p$} & \multirow[b]{2}{*}{$\begin{array}{l}\text { Time after injury } \\
\text { (h) }\end{array}$} & \multicolumn{2}{|c|}{ Ischemic injury } & \multirow[b]{2}{*}{$p$} \\
\hline & $\begin{array}{c}\text { Control } \\
\text { diet }\end{array}$ & $\begin{array}{c}\text { Deprived } \\
\text { diet }\end{array}$ & & & $\begin{array}{c}\text { Control } \\
\text { diet }\end{array}$ & $\begin{array}{c}\text { Deprived } \\
\text { diet }\end{array}$ & \\
\hline $\begin{array}{l}\text { Distance traveled by } \\
\text { foremost labeled cell } \\
(\mu) \dagger\end{array}$ & $\begin{array}{r}52 \pm 2 \\
158 \pm 5\end{array}$ & $\begin{array}{r}43 \pm 2 \\
120 \pm 3\end{array}$ & $\begin{array}{l}0.001 \\
0.001\end{array}$ & $\begin{array}{r}4 \\
24\end{array}$ & $\begin{array}{r}49 \pm 3 \\
231 \pm 7\end{array}$ & $\begin{array}{r}53 \pm 3 \\
201 \pm 5\end{array}$ & $\begin{array}{c}\text { NS } \\
0.005\end{array}$ \\
\hline Migration rate $(\mu / \mathrm{h})$ & 5.3 & 3.9 & & & 9.1 & 7.4 & \\
\hline
\end{tabular}

* Measurements based on a minimum of 10 crypt-villus units.

$\dagger^{3} \mathrm{H}$-thymidine injected at time of mucosal injury.

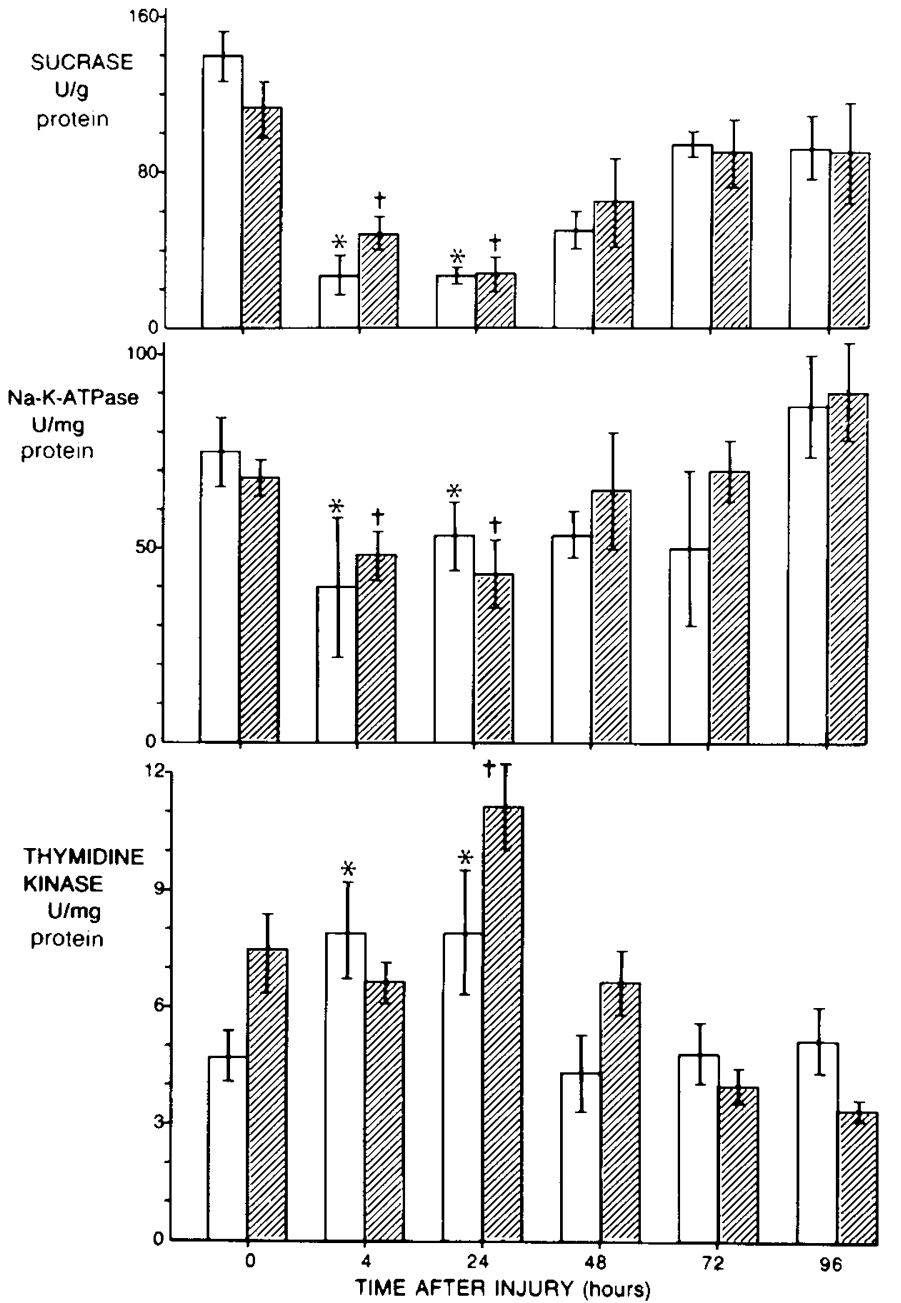

Fig. 3. Enzyme specific activities in small intestinal mucosal homogenates, control diet (open bars) and undernourished rabbits (shaded bars) after ischemic injury (mean \pm SEM). Sucrase and Na-K-ATPase activities similar in control diet and undernourished rabbits under all experimental conditions. Thymidine kinase activity increased in control diet rabbits at 4 and $24 \mathrm{~h}$, normal at $48 \mathrm{~h}$; in undernourished group, thymidine kinase increased at $24 \mathrm{~h}$, not at $4 \mathrm{~h}$, normal by $48 \mathrm{~h} .{ }^{*} p<0.05$ compared with control diet sham-operated group; $\uparrow p<0.05$ compared with sham undernourished.

luminal membrane function of the villus cell $(10,11)$. In shamoperated rabbits neither basal nor glucose-stimulated Na flux differed between diet groups. In rabbits fed the control diet, basal and glucose-stimulated $\mathrm{Na}$ fluxes, 24 and $72 \mathrm{~h}$ after ischemic injury, did not differ from sham-operated controls. In the malnourished rabbits glucose-stimulated $\mathrm{Na}$ absorption, blunted at $24 \mathrm{~h}$ compared with sham-operated animals, had recovered when measured $72 \mathrm{~h}$ after injury. Presumably, with the loss of villus cells, reflected by diminished disaccharidase activities $4 \mathrm{~h}$ after injury, the $\mathrm{Na}$ absorptive response to glucose did diminish even in control diet animals immediately after ischemic injury; therefore our normal 24 and $72 \mathrm{~h}$ control diet data probably represent recovery. Increments in $\Delta I s c$ after the addition of glucose did not differ between dietary groups. This $\Delta$ Isc in sham-operated groups (78 versus $84 \mu \mathrm{A}$, control versus malnourished) decreased at $24 \mathrm{~h}(39$ versus $21 \mu \mathrm{A})$ but returned to the level of shamoperated rabbits $72 \mathrm{~h}$ after injury.

\section{DISCUSSION}

A 6-wk period of dietary deprivation, which did alter intestinal epithelial proliferation in 10 -wk-old rabbits subjected to sham laparotomy, failed to affect structure or enzyme and transport function of uninjured jejunal epithelium. Preliminary studies had shown this deprivation to be as severe as these young animals could tolerate. In sham-operated rabbits, normal levels of mucosal disaccharidases and $\mathrm{Na}-\mathrm{K}$-ATPase activities and intact glucose-stimulated $\mathrm{Na}$ transport indicate that intestinal epithelial cell differentiation $(11,12)$ was preserved during a period of nutritional restriction sufficient to reduce body weight gain, and delay epithelial migration. This apparent functional resilience of the gut to semistarvation is suggested by earlier animal studies (13), although the response to starvation can differ depending on the species studied and the nature of the dietary deprivation. For example, in suckling animals during postnatal maturation of the gut, the functional impact of undernutrition seems greater than in mature animals because of its effect in delaying normal postnatal development patterns (1). Studies in man have shown marked structural and functional damage to the gut (14) in malnourished patients but these clinical findings may result, not from direct nutritional damage to the gut, but from coexistent disease such as enteric infestations or infections. Our current data reflect only qualitative characteristics of function not total functional capacity since the findings are related to the protein content of a segment of intestine.

The small intestinal injury in our rabbits by transient vascular injury was in keeping with previous experience using the technique in rats (3). After early loss of viable villus cells there was a relative decrease in a range of functions normally associated with differentiated villus cells (disaccharidases, Na-K-ATPase, glucose-stimulated $\mathrm{Na}$ transport). These findings, $4 \mathrm{~h}$ after clamping, were the same in control and undernourished groups. Not only were the initial mucosal injuries comparable, but no major differences between dietary groups were seen in the pattern of repair after this segmental lesion. Our data on cell migration show that enhanced migration rates seen in normally nourished rabbits after vascular injury were suppressed in the starved group 
Table 2. Small intestinal mucosa from control diet and deprived diet rabbits, studied in vitro; transmucosal Na fluxes, PD, Isc in sham-operated group and in groups 24 or $72 \mathrm{~h}$ after ischemic injury*

\begin{tabular}{|c|c|c|c|c|c|c|c|c|}
\hline & & & \multicolumn{2}{|c|}{ Sham } & \multicolumn{2}{|c|}{$24 \mathrm{H}$} & \multicolumn{2}{|c|}{$72 \mathrm{H}$} \\
\hline & & & Mean & SEM & Mean & SEM & Mean & SEM \\
\hline \multicolumn{9}{|l|}{ Control diet } \\
\hline \multirow[t]{10}{*}{$\mathrm{Na}$ flux $\left(\mu \mathrm{Eq} \cdot \mathrm{cm}^{-2} \cdot \mathrm{h}^{-1}\right)$} & & Basal & 8.2 & 0.5 & 8.6 & 0.5 & 8.2 & 0.3 \\
\hline & $J_{m \rightarrow s}^{N a}$ & Glucose & 10.7 & 0.6 & 9.3 & 0.5 & 10.5 & 0.5 \\
\hline & & $p$ & $<0.05$ & & NS & & $<0.05$ & \\
\hline & & Basal & 8.6 & 0.3 & 8.8 & 0.3 & 7.8 & 0.4 \\
\hline & $\mathbf{J}_{\mathrm{s} \rightarrow \mathrm{m}}^{\mathrm{Na}}$ & Glucose & 9.3 & 0.5 & 8.2 & 0.3 & 8.8 & 0.4 \\
\hline & & $p$ & NS & & NS & & NS & \\
\hline & & Basal & -0.4 & 0.4 & -0.2 & 0.2 & 0.4 & 0.4 \\
\hline & $\mathbf{J}_{\mathrm{net}}^{\mathrm{Na}}$ & Glucose & 1.4 & 0.5 & 1.1 & 0.4 & 1.7 & 0.9 \\
\hline & & $p$ & $<0.05$ & & $<0.05$ & & $<0.05$ & \\
\hline & & Basal & -1.8 & 0.1 & -1.4 & 0.2 & -1.8 & 0.1 \\
\hline \multirow[t]{3}{*}{$\mathrm{PD}(\mathrm{mV})$} & & Glucose & -4.5 & 0.2 & -2.8 & 0.2 & -3.5 & 0.2 \\
\hline & & $p$ & $<0.001$ & & $<0.001$ & & $<0.001$ & \\
\hline & & Basal & 39 & 1.4 & 29.4 & 4.0 & 49 & 3.5 \\
\hline \multirow[t]{2}{*}{ Isc $\left(\mu \mathrm{A} \cdot \mathrm{cm}^{-2}\right)$} & & Glucose & 117 & 3.8 & 69.1 & 6.3 & 111 & 13 \\
\hline & & $p$ & $<0.001$ & & $<0.001$ & & $<0.001$ & \\
\hline \multicolumn{9}{|l|}{ Deprived diet } \\
\hline \multirow[t]{10}{*}{ Na flux $\left(\mu \mathrm{Eq} \cdot \mathrm{cm}^{-2} \cdot \mathrm{h}^{-1}\right)$} & & Basal & 9.8 & 0.4 & 7.3 & 0.3 & 8.7 & 0.4 \\
\hline & $\mathbf{J}_{\mathrm{m} \rightarrow \mathrm{s}}^{\mathrm{Na}}$ & Glucose & 11.7 & 0.4 & 8.6 & 0.6 & 10.9 & 0.4 \\
\hline & & $p$ & $<0.05$ & & NS & & $<0.05$ & \\
\hline & & Basal & 9.8 & 0.5 & 8.3 & 0.2 & 8.8 & 9.3 \\
\hline & $\mathbf{J}_{\mathrm{s} \rightarrow \mathrm{m}}^{\mathrm{Na}}$ & Glucose & 10.3 & 0.5 & 8.2 & 0.4 & 0.2 & 0.2 \\
\hline & & $p$ & NS & & NS & & NS & \\
\hline & & Basal & -0.1 & 0.4 & 0.9 & 0.4 & -0.1 & 0.4 \\
\hline & $J_{\text {net }}^{\mathrm{Na}}$ & Glucose & 1.4 & 0.4 & 0.4 & 0.4 & 1.6 & 0.4 \\
\hline & & $p$ & $<0.05$ & & $<0.05$ & & $<0.05$ & \\
\hline & & Basal & -2.6 & 0.3 & -1.8 & 0.2 & -2.0 & 0.2 \\
\hline \multirow[t]{3}{*}{$\mathrm{PD}(\mathrm{mV})$} & & Glucose & -5.4 & 0.2 & -2.9 & 0.4 & -4.2 & 0.2 \\
\hline & & $p$ & $<0.001$ & & $<0.01$ & & $<0.001$ & \\
\hline & & Basal & 63.2 & 8.7 & 40 & 5.6 & 48.3 & 5.5 \\
\hline \multirow[t]{2}{*}{ Isc $\left(\mu \mathrm{A} \cdot \mathrm{cm}^{-2}\right)$} & & Glucose & 147.6 & 11 & 61.2 & 7.8 & 123.9 & 31 \\
\hline & & $p$ & $<0.001$ & & $<0.001$ & & $<0.001$ & \\
\hline
\end{tabular}

$* J_{\mathbf{m} \rightarrow s}^{N a}$, mucosa to serosa sodium flux; $J_{s \rightarrow m}^{N a}$, serosa to mucosa $N a$ flux; $J_{n e t}^{N a}$, net sodium flux.

probably reflecting reduced proliferative activity in the crypt epithelium. However, there was little evidence of a consistent functional impact of this altered cell renewal. Enzyme markers of differentiation (disaccharidases, Na-K-ATPase) were not altered by dietary deprivation during recovery from injury and only minor transport differences, with a slight delay in recovery of glucose-stimulated $\mathrm{Na}$ absorption, were observed. The delayed rise of thymidine kinase activity in the undernourished groups probably reflects the slow proliferative response apparent from our autoradiographic measurements. We conclude that delayed intestinal epithelial cell proliferation was not associated with altered cell differentiation as reflected by enzyme function.

In a previous study from our laboratory, structural and functional recovery of the small intestinal mucosa was delayed in chronically undernourished piglets after experimentally induced viral enteritis (2). This viral lesion, like that caused by ischemia, is one of villus cells primarily; unlike the ischemic lesion, the virus involves most of the small intestine rather than the short segment we exposed to vascular occlusion in the current experiments. We suspect that the chronically malnourished animal has sufficient endogenous reserves to cope efficiently with the increased demands of repair after a limited intestinal lesion whereas a more extensive injury may overwhelm those reserves.

Acknowledgments. The authors are grateful to Mr. J. MacLeod, Mrs. K. Streich, Mr. M. Khan, Mr. W. Wilson, Mrs. Anna Melnyk, and Mrs. Margaret Scott for their expert technical assistance and to Mrs. S. Goodman for secretarial assistance.

\section{REFERENCES}

1. Guiraldes E, Hamilton JR 1981 Effect of chronic malnutrition on intestinal structure, epithelial renewal and enzymes in suckling rats. Pediatr Res 15:930-934

2. Butzner D Butler DG, Miniats P, Hamilton JR 1985 Impact of chronic protein-calorie malnutrition on small intestinal repair after acute viral enteritis: a study in gnotobiotic piglets. Pediatr Res 19:476-481

3. Menge H, Robinson WL 1979 Early phase of jejunal regeneration after short term ischemia in the rat. Lab Invest 40:25-31

4. Kopriwa BM, Leblond CP 1962 Improvements in the coating techniques of radioautography. J Histochem Cytochem 10:269-284

5. Dahlqvist $H 1966$ Method for assay of intestinal disaccharidases. Anal Biochem 22:99-107

6. Kerzner B, Kelly MH, Gall DG, Hamilton JR 1977 Transmissible gastroenteritis. Na transport and the intestinal epithelium during the course of viral enteritis. Gastroenterology 72:457-461

7. Klemperer HG, Haynes GR 1968 Thymidine kinase in rat liver during development. Biochem J 108:541-546

8. Kelly MG, Butler DG, Hamilton JR 1972 Transmissible gastroenteritis in piglets: a model of infantile viral diarrhea. J Pediatr 80:925-931

9. McClung HJ, Butler DG, Kerzner B, Gall DG, Hamilton JR 1976 Transmissible gastroenteritis: mucosal ion transport in acute viral enteritis. Gastroenterology 70:1091-1095

10. Gall DG, Butler DG, Tepperman F, Hamilton JR 1974 Sodium ion transport in isolated intestinal epithelial cells. The effect of actively transported sugars on sodium ion efflux. Biochem Biophys Acta 339:291-302

11. Weiser MM 1975 Intestinal cell surface membrane glycoprotein synthesis. I. An indicator of cellular differentiation. J Biol Cell 248:2536-2541

12. Keljo DJ, MacLeod RJ, Perdue MH, Butler DG, Hamilton JR 1985 D-Glucose transport in piglet jejunal brush border membranes. Insights from a disease model. Am J Physiol 249:G751-G760.

13. McNeill LK, Hamilton JR 1971 The effect of fasting on disaccharidase activity in the rat small intestine. Pediatrics 47:65-72

14. James W 1971 Effects of protein-calorie malnutrition on intestinal absorption. Ann NY Acad Sci 176:244-261 